\title{
Effectiveness of PGPR Variety towards Quantity Improvement of Root Nodule in Mung Bean Cultivar (Vigna Radiata L.)
}

\author{
Lestari MP Alibasyah $^{1 *}$, Mahfudz ${ }^{2}$, Bahrudin $^{2}$, Astija $^{3}$ \\ ${ }^{1}$ Postgraduate Doctor of Agricultural Sciences, Tadulako University, Jl. Soekarno-Hatta Km 09, Palu 94118, Indonesia \\ ${ }^{2}$ Department of Agroecotechnology, Faculty of Agriculture, Tadulako University, Jl. Soekarno-Hatta Km 09, Palu 94118, \\ Indonesia \\ ${ }^{3}$ Department of Natural Education Science, Faculty of Teacher Training and Education Science, Tadulako University, Jl. \\ Soekarno-Hatta Km 09, Palu 94118, Indonesia \\ *Corresponding Author
}

\begin{abstract}
The enhancement of mungbean production has a vital role in supporting nutritious foods supply for human beings and sustaining soil productivity and fertility. Fixation bacteria that occupied symbiotically with legumes' root was also addressed as a nodulating root bacteria founded in PGPR (Plant Growth Promoting Rhizobacteria). Rhizobacteria play a role as natural fertilizer is proficient at ameliorating $\mathbf{N}$ availability in the plant, which could keep up legume productivity. The rhizobacteria stimulation is affected by its harmonious with plant cultivar. This research is experimental research to pursue the appropriate PGPR isolate with mungbean cultivar using a comprehensive random layout with a factorial scheme. The treatment in this research used a combination of two factors, precisely a cultivar factor that consists of three samples, $k 1$ (Vima 1 Cultivar), $\mathbf{k}_{2}$ (Vima 2 Cultivar), $k_{3}$ (Vima 3 Cultivar) and PGPR, which consist of $r_{0}$ (without PGPR), $r_{1}$ (Bamboo root), $r 2$ (Mungbean root) and $r_{3}$ (Sensitive Plant root) with three repetitions for each treatment. The outcome of this research showed a significant difference between cultivar and PGPR type through the quantity of root nodules enhancement $(p<0.05)$. By the amount of root nodule, demonstrated that each cultivar has one kind of PGPR which escalate the number of root nodule with the highest is at K3R3 treatment in 4 weeks after planting, 6 weeks after produced and 8 weeks after a planted period with $17.67,18.33$ dan 41.33 nodules respectively.
\end{abstract}

Keywords: Effectiveness, PGPR, Number of Root Nodule, Cultivar, Mungbean, Quality of Root Nodule

\section{INTRODUCTION}

$\mathrm{M}$ ung bean is a short-lived annual plant has a high competitive ability, grows on all types of agricultural soil and is able to adapt widely in various areas with hot climates. Until now, the demand for green beans, especially in Indonesia, continues to increase but is not followed by the amount of production (Audrey et al., 2021). Various factors cause a decrease in mung bean production, including low soil fertility, land conversion, unsupportive climatic factors, and inappropriate cultivation practices. Efforts to increase the productivity of mung bean can be done by improving the efficiency of fertilization and the number of plants per unit area (Gong et al., 2020; Favero et al., 2021). The high number of mung bean imports reflects interest in the production of beans, so it is expected to continue to increase in line with the increase in population and improvement in community nutrition.

The application of better cultivation techniques by choosing the right cultivar and giving specific rhizobacteria is one of the efforts made to support the achievement of increasing mung bean production. Rhizobium sp . bacteria can support the production of green bean plants in symbiosis with the roots of the host plant (Moncada et al., 2021; Yuan et al., 2021). This symbiosis forms root nodules that can serve as a source of $\mathrm{N}$ fertilizer which can have implications for increasing crop yields. Efforts to increase the yield of mung bean require quality root nodules (Brishti et al., 2021). Giving PGPR can help the symbiotic mechanism between the host plant and microbes in the roots. PGPR is able to produce plant hormones such as auxin, gibberellins and cytokinins, as phosphate solvents and $\mathrm{N}$ fixation (Bukhat et al., 2020; Narasimha Murthy et al., 2021; Essalimi et al., 2022). Thus, PGPR can act as a nutrient that functions as a bio stimulant by synthesizing and regulating the concentration of various types of growth regulators from the time of vegetative growth to the productive period. PGPR can also increase mineral levels and $\mathrm{N}$ fixation, increase plant tolerance to environmental stress, as a biofertilizer, biocontrol agent, protect plants from pathogens, increase the production of indole-3-acetic acid, secrete lytic enzymes.

Guimarães et al (2021) states that it is necessary to increase plant growth and protection against specific pathogens that PGPR can assist as soil microbes on plant roots in increasing production. PGPR can also produce plant hormones such as auxin, gibberellins and cytokinins, as phosphate solvents and $\mathrm{N}$ fixation (Zerrouk et al., 2020). Thus, PGPR can act as a nutrient that functions as a biostimulant by synthesizing and regulating the concentration of various growth regulators from vegetative growth to the productive period. The symbiotic form of rhizobacteria is optimal in the legume group (Fabaceae), such as green beans. 
The problems found in the research above are that PGPR has a specific effect on only one type of plant, so it is very important to know which PGPR isolate is suitable for certain plants so that production is maximized, another thing also concerns the effectiveness of PGPR isolates to increase $\mathrm{N}$ fixation (Li et al., 2020; Sonbarse et al., 2020). This phenomenon is suspected that the use of PGPR with specific isolates can have a significant effect on increasing the amount of mung bean production through increased $\mathrm{N}$ fixation. The use of PGPR can increase plant growth activity and can also produce IAA hormones, increase nutrient absorption and $\mathrm{N}$ fixation, and even produce compounds that are able to fight pathogens (Saleem et al., 2021). Utilization of rhizobia as inoculants of biological agents can increase the availability of $\mathrm{N}$ for plants, which in turn can support increased production of legumes. The effectiveness of rhizobia inoculation is influenced by the suitability of the rhizobia inoculants with the types and varieties of plants and soil types inoculated and is influenced by competition factors with indigenous rhizobia (Razakatiana et al., 2020).

\section{RESEARCH METHODS}

The research was conducted at the Biology Greenhouse, Faculty of Teacher Training and Education, Tadulako University. The tools used in this study were: small scope, manual scale, steamer, large pot, small basin, soil sieve, jeregen, digital scale, $10 \mathrm{~kg}$ polybag, sack (soil container), stereo microscope, centrifuge, mortar and pestle, scissors, test tube, dropper, razor, and spectrophotometer. The materials used in this study were: three cultivars of mung bean seeds, three types of PGPR. soil, NPK fertilizer, water, bamboo roots, mung bean roots, shy daughter plant roots, shrimp paste, bran, brown sugar, aquades.

\section{Research procedure}

This research is an experimental research which includes the following activities:

1. PGPR Lead Making

2. PGPR Culture Production

3. Making Planting Media

4. Green Bean Seed Planting

5. Green Bean Plant Maintenance

6. Measurement of root nodule quality including number of nodules, nodule diameter and absorbance were carried out in the laboratory.

7. Measuring the effect of PGPR on mung bean plants including number of pods, pod length, wet weight of seed pods, dry weight of seed pods b.

8. The results of the $\mathrm{N}$ fixation test as a symbiotic relationship between PGPR and mung bean cultivars in the microbiology laboratory of IPB.

Observations of samples included number of root nodules, quality of root nodules, and $\mathrm{N}$ fixation. Measurement of number and quality of root nodules used a UV-Vis
Spectrophotometer, while $\mathrm{N}$ fixation used the ARA (Acetylene Reduction Assay) method.

\section{Data analysis technique}

The data obtained will be analyzed using the 2-factor analysis of variance (Two-way ANOVA). If the calculated F results show significant results, then it is continued with the BNT test (Least Significant Difference) to find out whether there is a difference in average or more than 2 treatment groups.

\section{RESULTS AND DISCUSSION}

Measurement of mungbean growth was carried out for 3 times, namely at week 4 SMT (after planting), 6 SMT and 8 SMT. There were several response variables observed, namely the number of root nodules, root nodule diameter, root nodule quality, and $\mathrm{N}$ fixation through the ARA (Acetyllene Reduction Assays) method.

The results of the growth measurements were then performed with an ANOVA test to determine whether the combination of PGPR and cultivars had an effect on increasing the number, diameter and quality of root nodules in mung bean cultivars by looking at the response variables. The results of hypothesis testing are as follows:

1. Based on the analysis of variance, Fcount $<$ Ftable at all weeks after planting (MST). Thus, H1A was rejected and H0A was accepted, i.e. there was no significant difference in the number of root nodules, root nodule quality and nitrogen fixation from different cultivars.

2. Based on the analysis of variance, Fcount $>$ Ftable on the number of root nodules in all MST, then H0B was rejected and H1B was accepted, that is, there was a significant difference in the number of root nodules from different PGPR, while the quality of root nodules and nitrogen fixation Fcount $<$ Ftable then, H1B was rejected and H0B accepted that there was no significant difference in the quality of root nodules and nitrogen fixation of different PGPR.

3. Based on analysis of variance, Fcount $>$ Ftable on the number of nodules in all MST, then HOAB was rejected and $\mathrm{H} 1 \mathrm{AB}$ was accepted, that is, there was a significant difference in the number of root nodules from different cultivars and PGPR combinations, while the quality of root nodules and nitrogen fixation Fcount < Ftable then, $\mathrm{H} 1 \mathrm{AB}$ was rejected and $\mathrm{H} 0 \mathrm{AB}$ was accepted, that is, there was no significant difference in the quality of root nodules and nitrogen fixation from different combinations of cultivars and PGPR.

\section{Number of Green Bean Nodules}

The results of data analysis on the number of root nodules based on variance showed that FTable < F Count in 
all weeks after planting (MST), then H1A was rejected and H0A was accepted, seen from the cultivar as follows.

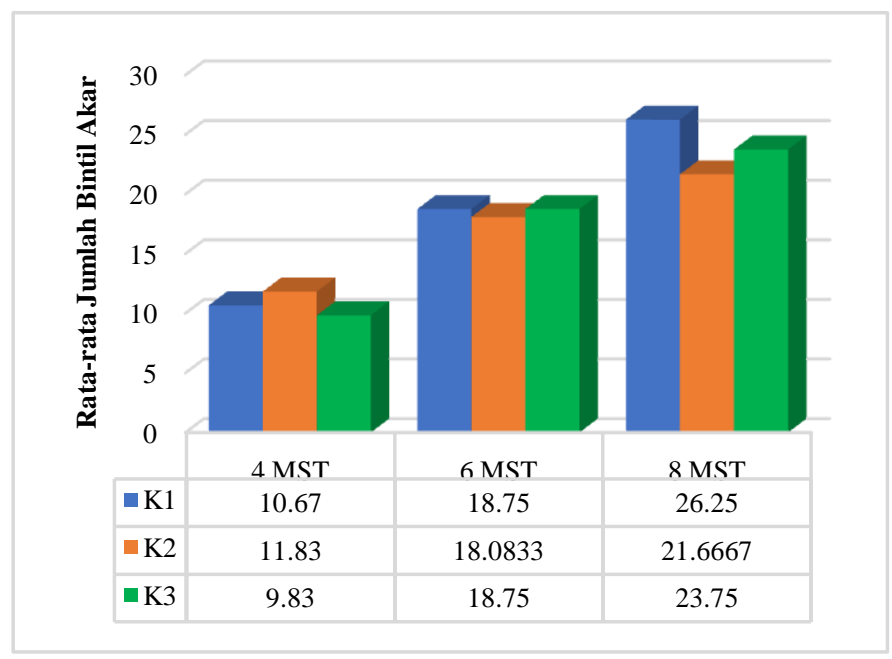

Figure 1 The average number of nodules on the Vima 1 (K1), Vima 2 (K2) and Vima 3 (K3) cultivars.
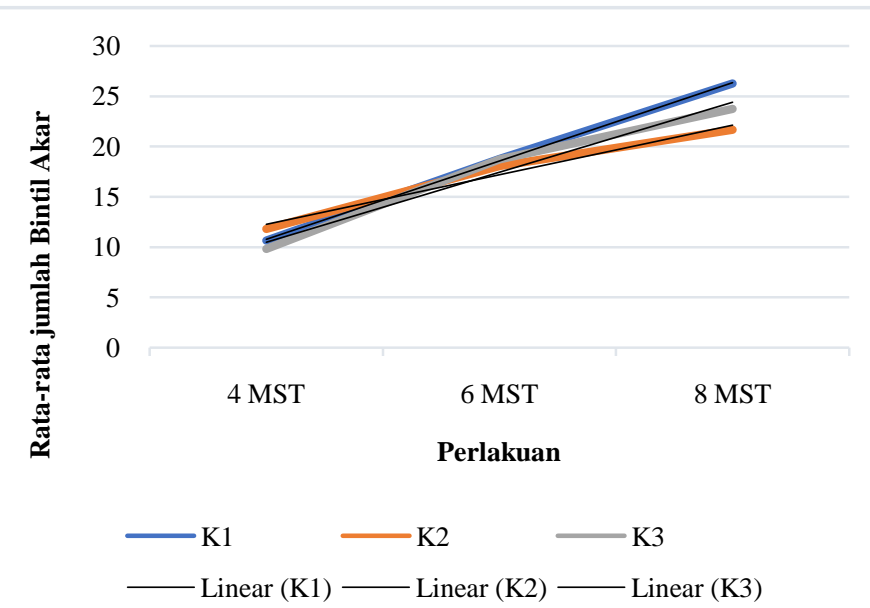

Figure 2 Regression Equation Graph

Regression Equation

\begin{tabular}{|c|c|c|}
\hline Treatment & Regression Equation & $\mathrm{R} 2$ \\
\hline $\mathrm{K} 1$ & $\mathrm{y}=7.79 \mathrm{x}+2.9767$ & 0.9995 \\
\hline $\mathrm{K} 2$ & $\mathrm{y}=4.92 \mathrm{x}+7.3533$ & 0.9762 \\
\hline $\mathrm{K} 3$ & $\mathrm{y}=6.96 \mathrm{x}+3.5233$ & 0.9742 \\
\hline
\end{tabular}

Figure 1 shows that the cultivar at the age of 4 MST had no significant difference in the number of root nodules with the highest number of root nodules in the Vima 2 cultivar, 11.83 and the lowest in the Vima 3 cultivar, 9.83. Likewise, the age of 6 WAP also appeared to be insignificantly different with the highest root nodule on the Vima 1 cultivar and Vima 3 cultivar, which was 18.75 and the lowest on the Vima 2 cultivar, which was 18.08 . vima 1 cultivar is 26.25 and the lowest in vima 2 cultivar is 21.67
Meanwhile, the number of root nodules is also influenced by the type of PGPR used as the results are presented in Figure 3.

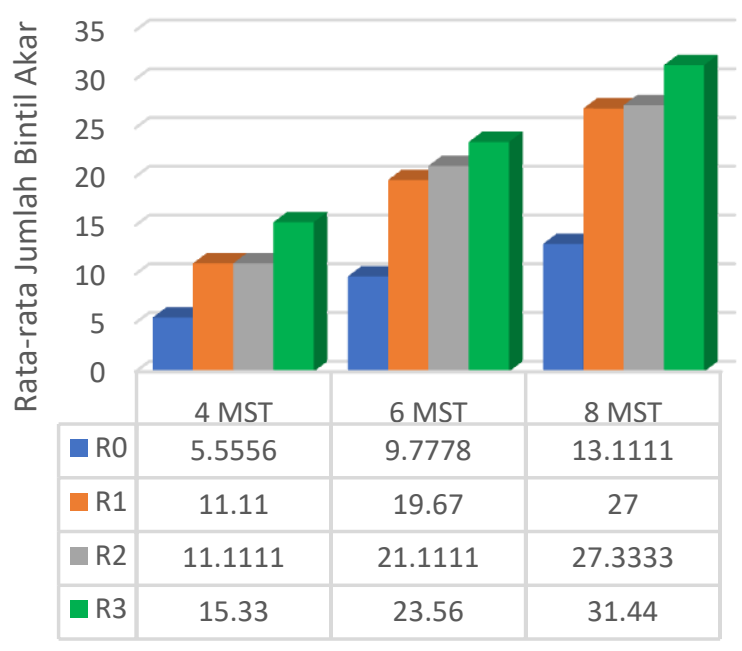

Perlakuan

Figure 3 Number of root nodules from mung bean treated with: no PGPR (R0), bamboo root PGPR (R1), mung bean root PGPR (R2) and shy daughter PGPR (R3).

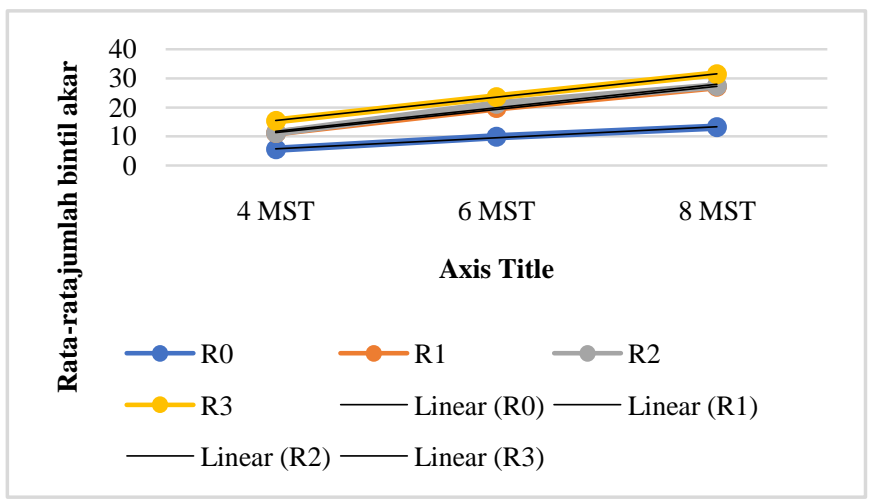

Figure 4 Regression Equation Graph

Regression Equation

\begin{tabular}{|c|c|c|}
\hline Treatment & Regression Equation & R2 \\
\hline R0 & $\mathrm{y}=3.775 \mathrm{x}+1.9333$ & 0.9954 \\
\hline R1 & $\mathrm{y}=7.945 \mathrm{x}+3.37$ & 0.998 \\
\hline R2 & $\mathrm{y}=8.11 \mathrm{x}+3.63$ & 0.9822 \\
\hline R3 & $\mathrm{y}=8055 \mathrm{x}+7.3333$ & 0.9998 \\
\hline
\end{tabular}

Figure 3 shows that the administration of PGPR at the age of 4 WAP was significantly different in the number of root nodules in the R0 treatment compared to the PGPR treatment of bamboo roots, PGPR of mung bean roots and PGPR of Putri malu roots with the highest number of root nodules in the treatment of PGPR root of Putri malu, namely 15.33 and the lowest in treatment R0 is 5.56. Same with age 4 WAP, the number of root nodules at age 6 WAP was significantly 
different in R0 treatment compared to PGPR treatment of mung bean roots and PGPR of Putri malu roots but not significantly different from PGPR of bamboo roots with the highest number in PGPR treatment of Putri malu roots, namely 23.56 and The lowest was in the treatment without PGPR, which was 9.78, as well as at the age of 8 WAP, there was a significant difference in the treatment without PGPR compared to the PGPR treatment with bamboo roots,

The results showing the combination of cultivars and types of PGPR on the number of root nodules are presented in Figure 5

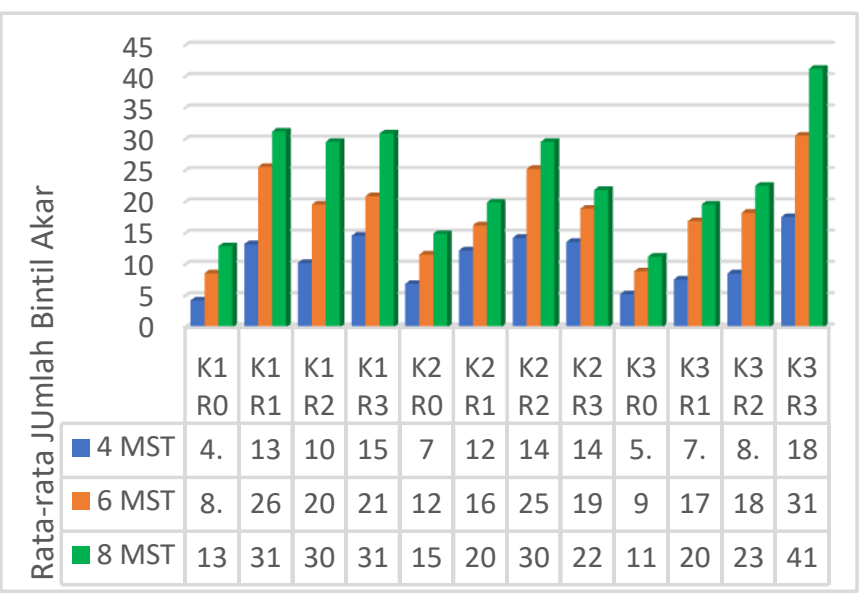

Figure 5 The number of root nodules based on the combination of cultivars and types of PGPR.

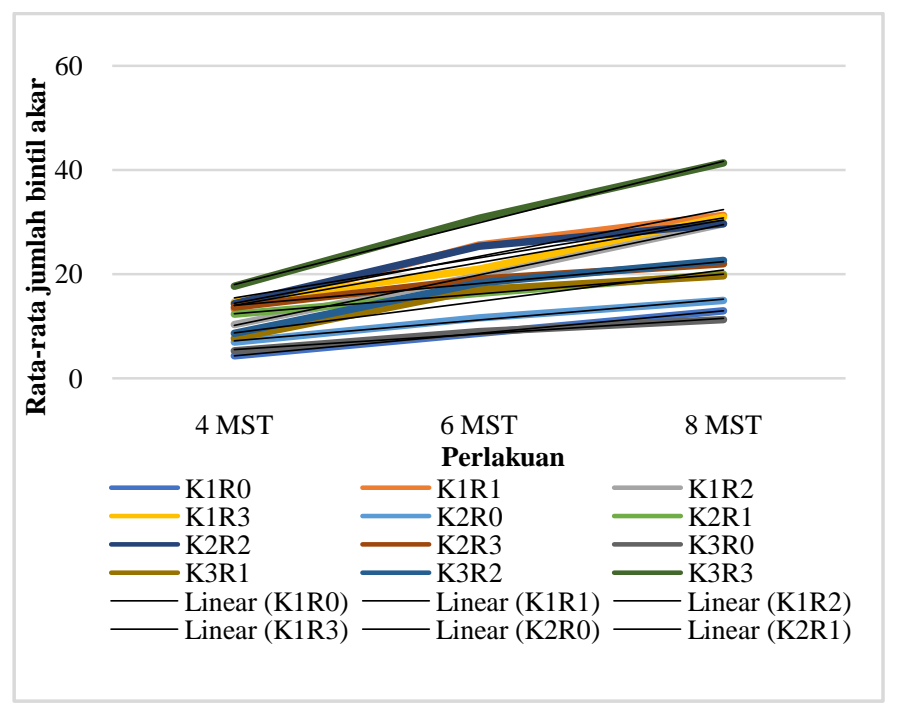

Figure 6 Regression Equation Graph

Regression Equation

\begin{tabular}{|c|c|c|}
\hline Treatment & Regression Equation & $\mathrm{R} 2$ \\
\hline K1R0 & $\mathrm{y}=4.335 \mathrm{x}-0.0033$ & 1 \\
\hline K1R1 & $\mathrm{y}=9 \mathrm{x}+5.4433$ & 0.9561 \\
\hline K1R2 & $\mathrm{y}=9.67 \mathrm{x}+0.55$ & 0.9996 \\
\hline K1R3 & $\mathrm{y}=8.165 \mathrm{x}+5.8933$ & 0.9834 \\
\hline K2R0 & $\mathrm{y}=4 \mathrm{x}+3.2233$ & 0.9907 \\
\hline
\end{tabular}

\begin{tabular}{|c|c|l|}
\hline K2R1 & $y=3.835 x+8.55$ & 0.9994 \\
\hline K2R2 & $y=7.67 x+7.77$ & 0.9409 \\
\hline K2R3 & $y=7 x+2.5567$ & 0.9541 \\
\hline K3R0 & $y=3 x+2.5533$ & 0.9836 \\
\hline K3R1 & $y=6 x+2.78$ & 0.9069 \\
\hline K3R2 & $y=7 x+2.5567$ & 0.9541 \\
\hline K3R3 & $y=11.83 x+6.23$ & 0.9968 \\
\hline
\end{tabular}

Figure 5 shows that the combination of cultivars and types of PGPR on the number of root nodules at the age of 4 WAP was significantly different, with the highest number of root nodules in the treatment of Vima 3 PGPR PGPR of Putri malu root, which was 17.67 and the lowest in the treatment of Vima 1 cultivar without PGPR K1R0 which was 4.33 , while in age 6 MST showed a significant difference in the treatment of Vima 1 cultivar without PGPR compared to the treatment of K1R1, K1R2, K1R3, K2R2, K2R3, K3R2, K3R3 and not significantly different from other treatments, with the highest root nodules in the treatment of the Vima 3 PGPR cultivar, the roots of the shy daughter. (K3R3) was 30.67 and the lowest was in the treatment of Vima 1 cultivar without PGPR (K1R0) which was 8.67. Likewise, the age of 8 MST showed a significant difference in the treatment of Vima 1 cultivars without PGPR (K1R0) compared to K1R1, K1R2, K1R3, K2R2,

Cultivars and PGPR interaction analysis on the number of root nodules. The results of the analysis of diversity showed that the treatment of cultivars, PGPR and their interactions showed a very significant effect on the number of root nodules at 4,6 and 8 weeks after planting while other ages had no significant effect. The average number of root nodules at the age of 4 WAP is presented in the table below.

Table1 Effect of PGPR Cultivars and rhizobacteria on Number of Root Nodules in Mung Bean Plants Age 4 WAP

\begin{tabular}{|c|c|c|c|c|}
\hline Treatment & $\mathrm{R}_{0}$ & $\mathrm{R}_{1}$ & $\mathrm{R}_{2}$ & $\mathrm{R}_{3}$ \\
\hline $\mathrm{K}_{1}$ & ${ }_{\mathrm{p}} 4.33 \mathrm{a}$ & ${ }_{\mathrm{q}} 13.33 \mathrm{~b}$ & ${ }_{\mathrm{p}} 10.33 \mathrm{~b}$ & ${ }_{\mathrm{p}} 14.67 \mathrm{~b}$ \\
\hline $\mathrm{K}_{2}$ & ${ }_{\mathrm{p}} 7.00 \mathrm{a}$ & ${ }_{\mathrm{q}} 12.33 \mathrm{a}$ & ${ }_{\mathrm{q}} 14.33 \mathrm{a}$ & ${ }_{\mathrm{p}} 13.67 \mathrm{a}$ \\
\hline $\mathrm{K}_{3}$ & ${ }_{\mathrm{p}} 5.33 \mathrm{a}$ & ${ }_{\mathrm{p}} 7.67 \mathrm{~b}$ & ${ }_{\mathrm{p}} 8.67 \mathrm{~b}$ & ${ }_{\mathrm{p}} 17.67 \mathrm{c}$ \\
\hline
\end{tabular}

Note: numbers followed by the same letter in the same column $(a, b, c)$ and row $(\mathrm{p}, \mathrm{q})$ are not different at 5\% DMRT test level

Each cultivar of mungbean given PGPR will be different to the number of root nodules produced at the age of 4 WAP (Table 1). Vima 1 cultivars that were not inoculated with PGPR produced fewer root nodules than those treated with PGPR and were significantly different. Vima 2 cultivars did not respond differently when given PGPR and did not differ from those not inoculated with PGPR. Vima 3 cultivars gave a different response when given PGPR to the number of roots formed. The treatment that was not inoculated with PGPR was different from the treatment given by PGPR, and the administration of PGPR from the roots of the shy daughter 
resulted in the highest number of root nodules compared to the other treatments. The cultivar response will be the same if PGPR is not given.

Table2 Effect of PGPR Cultivars and rhizobacteria on the Number of Root Nodules in Mung Beans at 6 WAP

\begin{tabular}{|c|c|c|c|c|}
\hline Treatment & $\mathrm{R}_{0}$ & $\mathrm{R}_{1}$ & $\mathrm{R}_{2}$ & $\mathrm{R}_{3}$ \\
\hline $\mathrm{K}_{1}$ & ${ }_{\mathrm{p}} 8.67 \mathrm{a}$ & ${ }_{\mathrm{q}} 25.67 \mathrm{~b}$ & ${ }_{\mathrm{p}} 19.67 \mathrm{~b}$ & ${ }_{\mathrm{p}} 21.00 \mathrm{~b}$ \\
\hline $\mathrm{K}_{2}$ & ${ }_{\mathrm{p}} 11.67 \mathrm{a}$ & ${ }_{\mathrm{p}} 16.33 \mathrm{a}$ & ${ }_{\mathrm{q}} 25.33 \mathrm{a}$ & ${ }_{\mathrm{p}} 19.00 \mathrm{a}$ \\
\hline $\mathrm{K}_{3}$ & ${ }_{\mathrm{p}} 9.00 \mathrm{a}$ & ${ }_{\mathrm{p}} 17,00 \mathrm{~b}$ & ${ }_{\mathrm{p}} 18.33 \mathrm{~b}$ & ${ }_{\mathrm{p}} 30.67 \mathrm{~b}$ \\
\hline
\end{tabular}

Note: numbers followed by the same letter in the same column $(a, b, c)$ and row $(\mathrm{p}, \mathrm{q})$ are not different at $5 \%$ DMRT test level

The vima 1 cultivar produced the highest number of root nodules when given PGPR bamboo roots and was different from other treatments at the age of 6 WAP (Table 2). The use of green bean root PGPR resulted in the highest number of root nodules compared to other treatments. The administration of PGPR from the roots of the shy daughter on the Vima 3 cultivar resulted in the best response compared to other treatments. Different responses will be shown by each cultivar if it is not given PGPR at the age of 6 MST. Vima 3 cultivar produced the best number of root nodules compared to other cultivars.

Table3 Effect of PGPR Cultivars and Rhizobacteria on Number of Root Nodules in Mung Bean Plants Age 8 WAP

\begin{tabular}{|c|c|c|c|c|}
\hline Treatment & $\mathrm{R}_{0}$ & $\mathrm{R}_{1}$ & $\mathrm{R}_{2}$ & $\mathrm{R}_{3}$ \\
\hline $\mathrm{K}_{1}$ & ${ }_{\mathrm{p}} 13.00 \mathrm{a}$ & ${ }_{\mathrm{q}} 31.33 \mathrm{~b}$ & ${ }_{\mathrm{p}} 29.67 \mathrm{~b}$ & ${ }_{\mathrm{p}} 31.00 \mathrm{~b}$ \\
\hline $\mathrm{K}_{2}$ & ${ }_{\mathrm{p}} 15.00 \mathrm{a}$ & ${ }_{\mathrm{p}} 20.00 \mathrm{a}$ & ${ }_{\mathrm{p}} 29.67 \mathrm{~b}$ & ${ }_{\mathrm{p}} 22.00 \mathrm{a}$ \\
\hline $\mathrm{K}_{3}$ & ${ }_{\mathrm{p}} 11.33 \mathrm{a}$ & ${ }_{\mathrm{p}} 19.67 \mathrm{a}$ & ${ }_{\mathrm{p}} 22.67 \mathrm{a}$ & ${ }_{\mathrm{p}} 41.33 \mathrm{~b}$ \\
\hline
\end{tabular}

Note: numbers followed by the same letter in the same column $(a, b, c)$ and row $(p, q)$ are not different at 5\% DMRT test level

The use of the Vima 1 cultivar that was given PGPR from the roots of the shy daughter resulted in the highest number of root nodules compared to other treatments and was different from that without PGPR and did not differ from other sources of PGPR at the age of 8 WAP (Table 3). The highest number of root nodules was produced when green bean root PGPR was given to Vima 2 cultivar and it was different from other treatments. The application of PGPR to the roots of the shy daughter of the Vima 3 cultivar resulted in the highest number of root nodules compared to other treatments. The same cultivar response would be seen if green bean root PGPR was given, Putri roots were embarrassed and not given PGPR at the age of 8 WAP. However, the application of PGPR to the roots of the shy daughter of Vima 3 resulted in the highest number of root nodules compared to other treatments.

\section{Root Nodule Diameter ( $\mathrm{mm}$ )}

The results of data analysis of large root nodules at the age of 4 WAP, 6 WAP, 8 WAP were seen from the cultivars as follows.

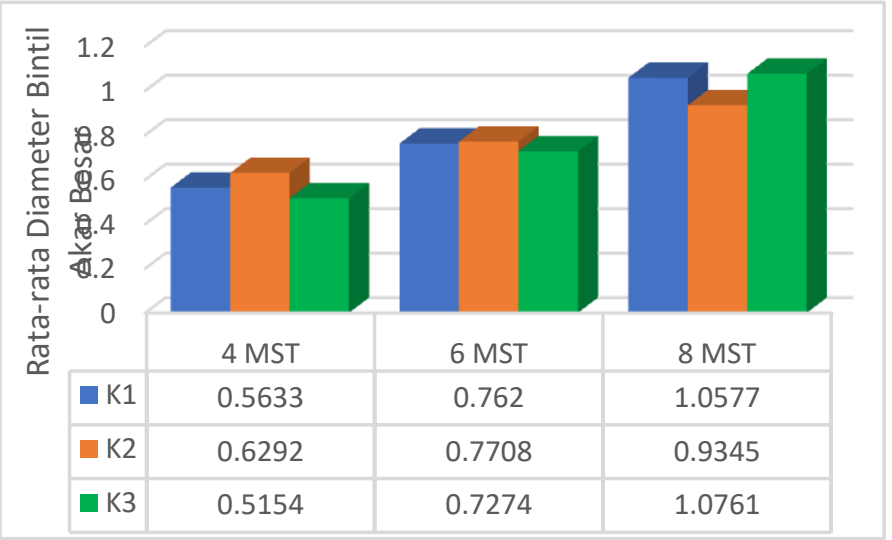

Figure 7 Average Diameter of Large Nodules on Cultivars Vima $1\left(\mathrm{~K}_{1}\right)$, Cultivars Vima $2\left(\mathrm{~K}_{2}\right)$ and Cultivars Vima $3\left(\mathrm{~K}_{3}\right)$.Root

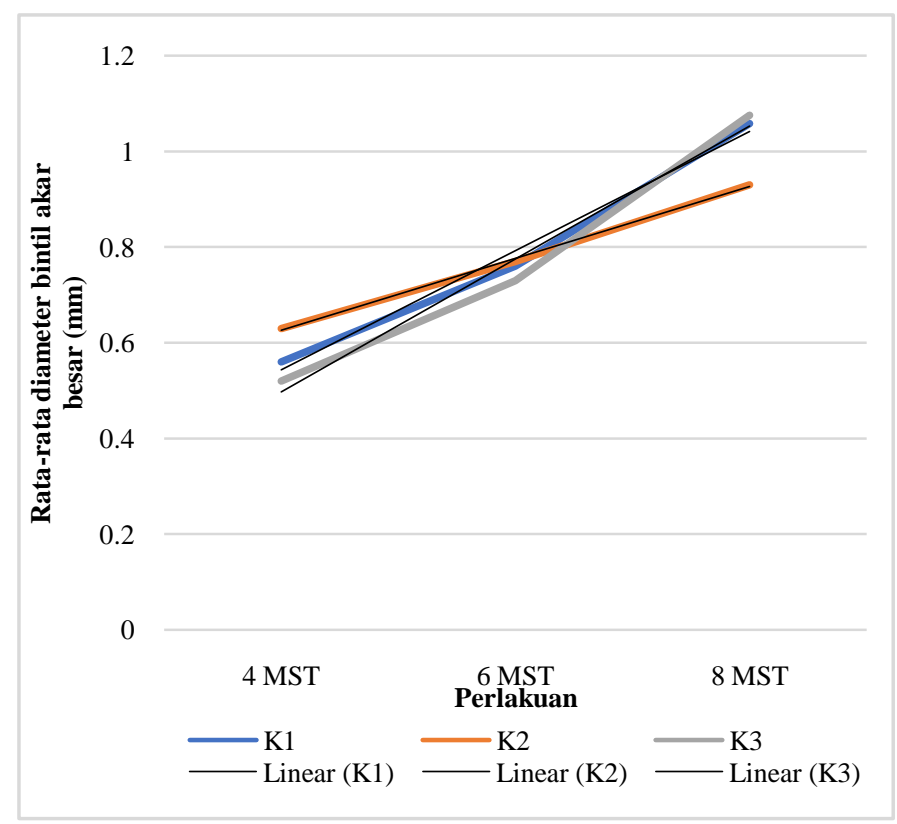

Picture 8 Regression Equation Graph

Regression Equation

\begin{tabular}{|c|c|c|}
\hline Treatment & Regression Equation & $\mathrm{R} 2$ \\
\hline $\mathrm{K} 1$ & $\mathrm{y}=0.249 \mathrm{x}+0.2947$ & 0.9873 \\
\hline $\mathrm{K} 2$ & $\mathrm{y}=0.15 \mathrm{x}+0.4767$ & 0.9985 \\
\hline $\mathrm{K} 3$ & $\mathrm{y}=0.278 \mathrm{x}+0.2193$ & 0.9804 \\
\hline
\end{tabular}

Figure 7 shows the results that were not significantly different at the age of $4 \mathrm{WAP}$, with the highest value in the treatment of the Vima 2 cultivar, which was $0.63 \mathrm{~mm}$ and the lowest at the treatment of the Vima 3 cultivar, which was 0.52 $\mathrm{mm} .0 .77 \mathrm{~mm}$ and the lowest in Vima 3 cultivar was $0.73 \mathrm{~mm}$, at the age of 8 WAT also showed no significant difference with the highest value in the Vima 3 cultivar treatment which was $1.076 \mathrm{~mm}$ and the lowest in the Vima 2 cultivar treatment $0.93 \mathrm{~mm}$.

Furthermore, based on the effect of the type of PGPR on the diameter of large root nodules as follows. 


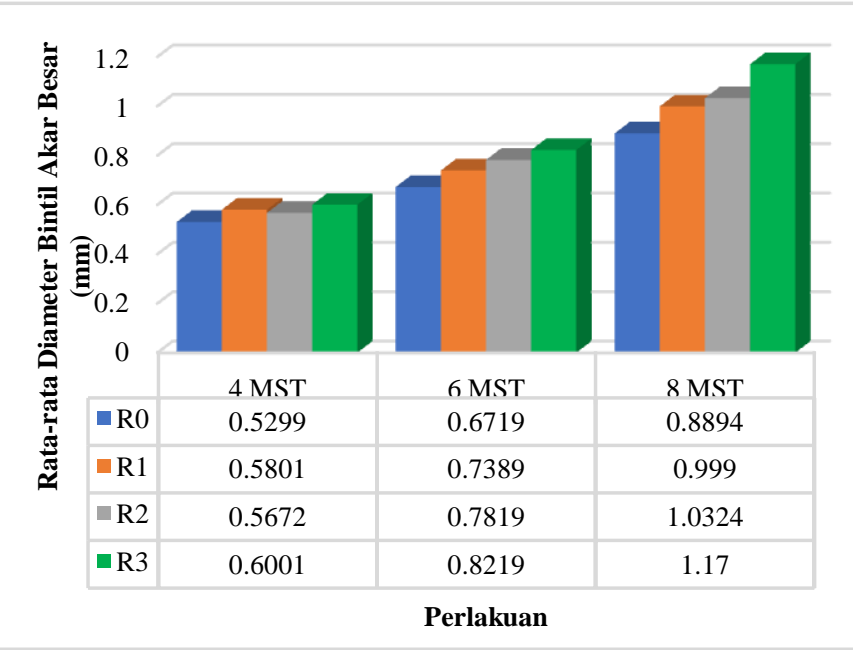

Figure 9 Diameter of large root nodules from green peas treated with: without PGPR $\left(\mathrm{R}_{0}\right)$, bamboo root PGPR $\left(\mathrm{R}_{1}\right)$, mung bean root PGPR $\left(\mathrm{R}_{2}\right)$ and shy daughter PGPR $\left(\mathrm{R}_{3}\right)$.

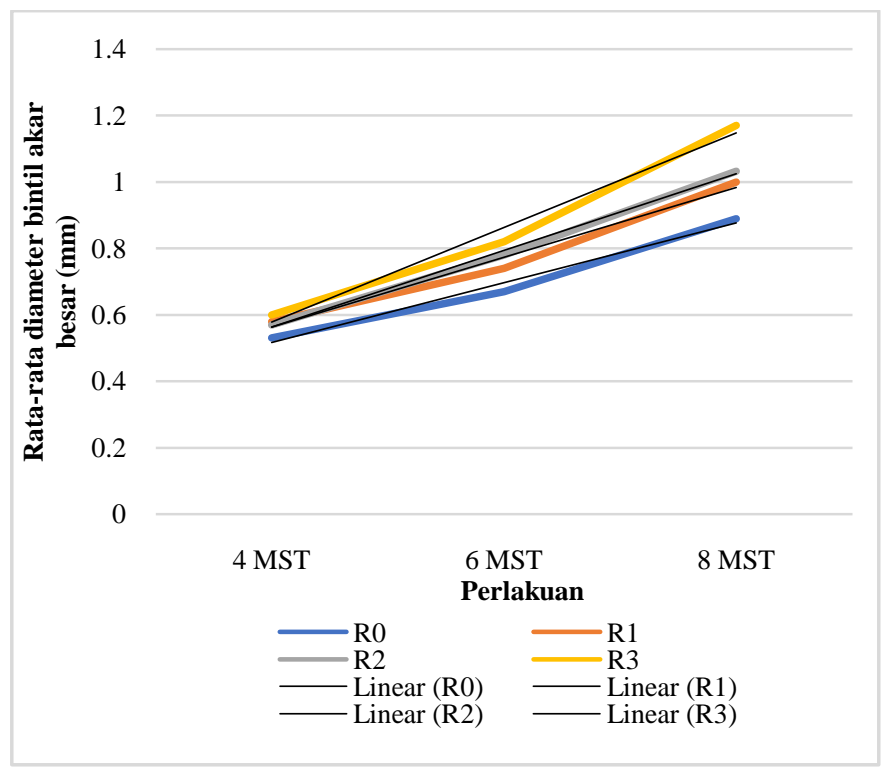

Figure 9 Regression Equation Graph

Regression Equation

\begin{tabular}{|c|c|c|}
\hline Treatment & Regression Equation & $\mathrm{R} 2$ \\
\hline R0 & $\mathrm{y}=0.18 \mathrm{x}+0.3367$ & 0.9838 \\
\hline $\mathrm{R} 1$ & $\mathrm{y}=0.231 \mathrm{x}+0.332$ & 0.9973 \\
\hline $\mathrm{R} 2$ & $\mathrm{y}=0.231 \mathrm{x}+0.332$ & 0.9973 \\
\hline R3 & $\mathrm{y}=0.285 \mathrm{x}+0.2933$ & 0.983 \\
\hline
\end{tabular}

Figure 9 shows the results that were not significantly different from the PGPR type treatment on the diameter of large root nodules at the age of 4 WAP, with the highest value in the PGPR treatment for the roots of the shy daughter of $0.60 \mathrm{~mm}$ and the lowest in the treatment without PGPR, which was $0.53 \mathrm{~mm}$, as well as at the age of 6 WAP the difference was not significant. with the highest value in the PGPR treatment of the roots of the shy princess, namely 0.82 $\mathrm{mm}$ and the lowest in the treatment without PGPR, namely $0.67 \mathrm{~mm}$, at the age of $8 \mathrm{MST}$ also showed an insignificant difference with the highest value in the PGPR treatment of the roots of the malu daughter which was $1.17 \mathrm{~mm}$ and the lowest in the treatment without PGPR, namely $0.89 \mathrm{~mm}$.

The results showing the combination of cultivars and types of PGPR $\mathrm{p}$ on the diameter of large root nodules are presented in Figure 11

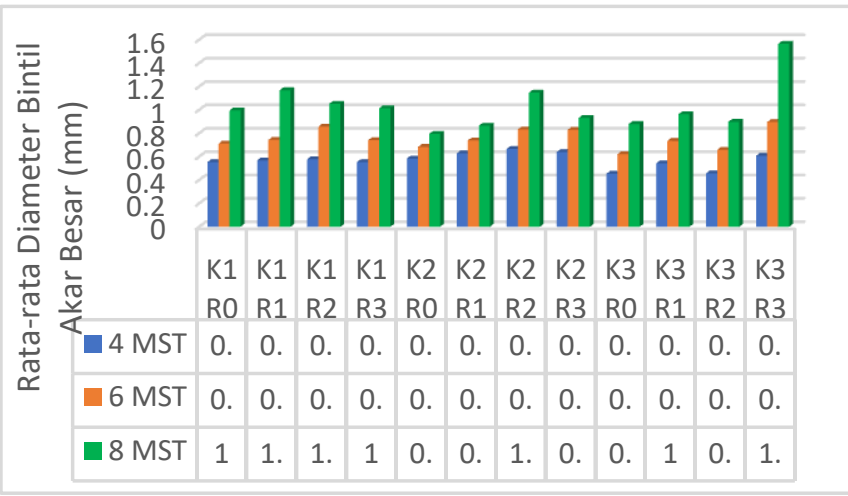

Picture 10 Diameter of large root nodules based on the combination of cultivars and types of PGPR

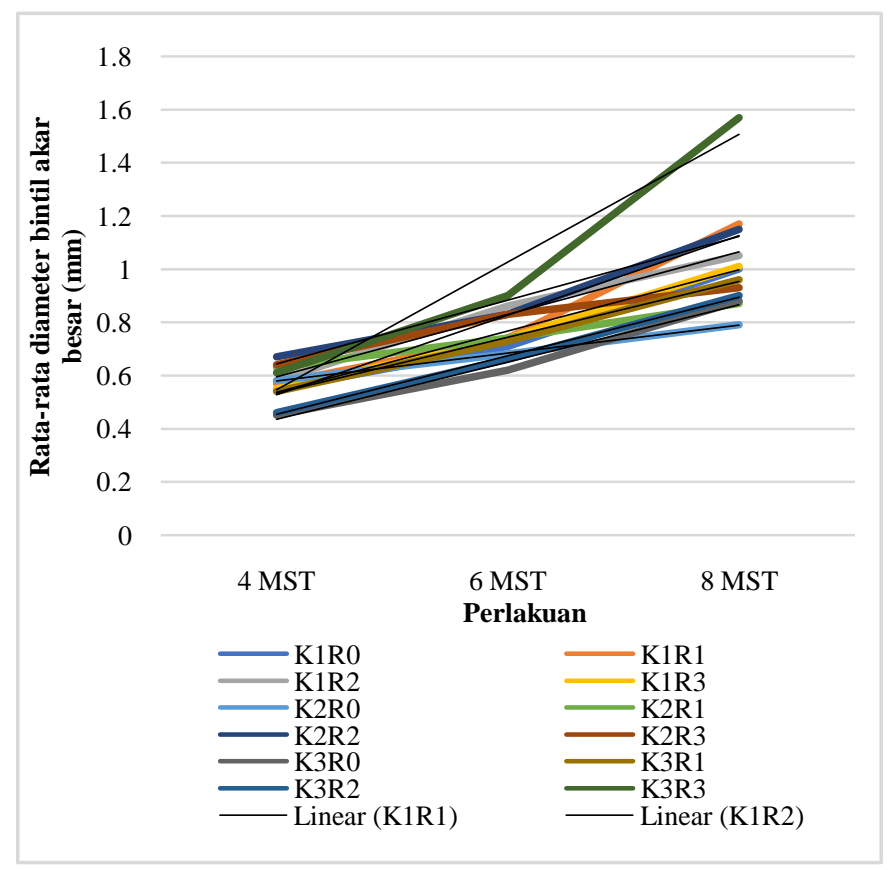

Picture 11 Regression Equation Graph

Regression Equation

\begin{tabular}{|c|c|c|}
\hline Treatment & Regression Equation & R2 \\
\hline K1R0 & $\mathrm{y}=0.225 \mathrm{x}+0.3033$ & 0.9729 \\
\hline K1R1 & $\mathrm{y}=0.3 \mathrm{x}+0.2267$ & 0.9411 \\
\hline K1R2 & $\mathrm{y}=0.235 \mathrm{x}+0.36$ & 0.9879 \\
\hline K1R3 & $\mathrm{y}=0.23 \mathrm{x}+0.3067$ & 0.99 \\
\hline K2R0 & $\mathrm{y}=0.105 \mathrm{x}+0.4733$ & 0.9992 \\
\hline
\end{tabular}




\begin{tabular}{|c|c|c|}
\hline K2R1 & $y=0.21 x+0.3233$ & 0.997 \\
\hline K2R2 & $y=0.24 x+0.4033$ & 0.9643 \\
\hline K2R3 & $y=0.145 x+0.51$ & 0.9689 \\
\hline K3R0 & $y=0.215 x+0.22$ & 0.9856 \\
\hline K3R1 & $y=0.21 x+0.3233$ & 0.997 \\
\hline K3R2 & $y=0.22 x+0.2333$ & 0.9973 \\
\hline K3R3 & $y=0.48 x+0.0667$ & 0.9504 \\
\hline
\end{tabular}

Figure 12 shows the results that are not significantly different from the combination of cultivars with the type of PGPR on the diameter of large root nodules at the age of 4 WAP, with the highest value in the treatment of cultivar Vima 2 PGPR mung bean root (K2R2) which is $0.67 \mathrm{~mm}$ and the lowest is in the treatment of cultivar Vima 3 without PGPR ( K3R0) was $0.45 \mathrm{~mm}$, as well as at the age of $6 \mathrm{WAP}$, the difference was not significant with the highest value in the treatment of cultivar Vima 3 PGPR root of Putri malu (K3R1) which was $0.90 \mathrm{~mm}$ and the lowest was in cultivar Vima 3 without PGPR (K3R0) which was $0.62 \mathrm{~mm}$, at age $8 \mathrm{MST}$ also showed an insignificant difference with the highest value in the treatment of cultivar Vima 3 PGPR root of Putri malu (K3R3) which was $1.57 \mathrm{~mm}$ and the lowest value in the treatment of cultivar Vima 2 without PGPR (K2R0) which was $0.79 \mathrm{~mm}$.

Furthermore, the results of data analysis on the diameter of small root nodules based on cultivars are presented as follows:

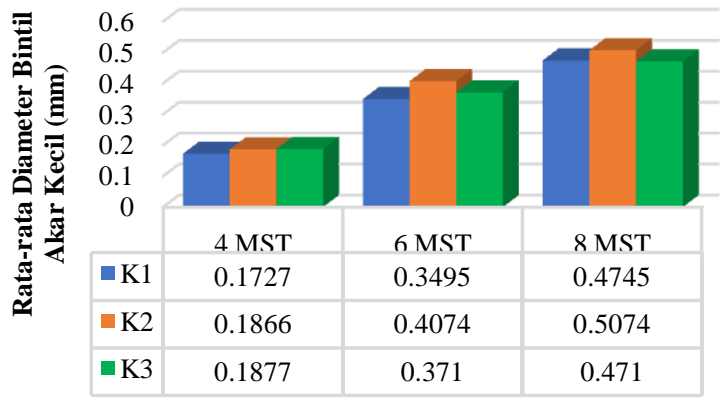

Figure 12 Average Diameter of Small Nodules in Cultivar Vima $1\left(\mathrm{~K}_{1}\right)$, Cultivars Vima $2\left(\mathrm{~K}_{2}\right)$ and Cultivars Vima $3\left(\mathrm{~K}_{3}\right)$

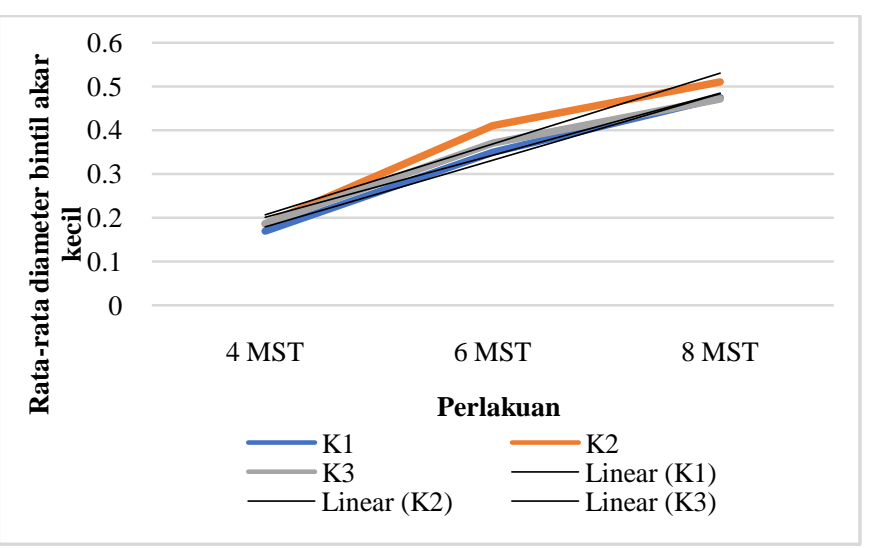

Figure 13 Regression Equation Graph
Regression Equation

\begin{tabular}{|c|c|c|}
\hline Treatment & Regression Equation & $\mathrm{R} 2$ \\
\hline $\mathrm{K} 1$ & $\mathrm{y}=0.142 \mathrm{x}+0.0587$ & 0.973 \\
\hline $\mathrm{K} 2$ & $\mathrm{y}=0.162 \mathrm{x}+0.0447$ & 0.9534 \\
\hline $\mathrm{K} 3$ & $\mathrm{y}=0.142 \mathrm{x}+0.0587$ & 0.973 \\
\hline
\end{tabular}

Figure 13 shows the results that were not significantly different from the cultivar treatment on the diameter of small root nodules at the age of $4 \mathrm{WAP}$, with the highest value in the treatment of the Vima 3 cultivar which was $0.187 \mathrm{~mm}$ and the lowest in the treatment of the Vima 1 cultivar, which was $0.17 \mathrm{~mm}$. the highest in the Vima 2 cultivar treatment was $0.41 \mathrm{~mm}$ and the lowest was in the Vima 1 cultivar $0.35 \mathrm{~mm}$, at the age of $8 \mathrm{MST}$ also showed an insignificant difference with the highest value in the Vima 2 cultivar treatment, $0.51 \mathrm{~mm}$ and the lowest in the Vima 3 cultivar treatment, $0.471 \mathrm{~mm}$.

Furthermore, the results of data analysis on the diameter of small root nodules based on the type of PGPR are as follows.

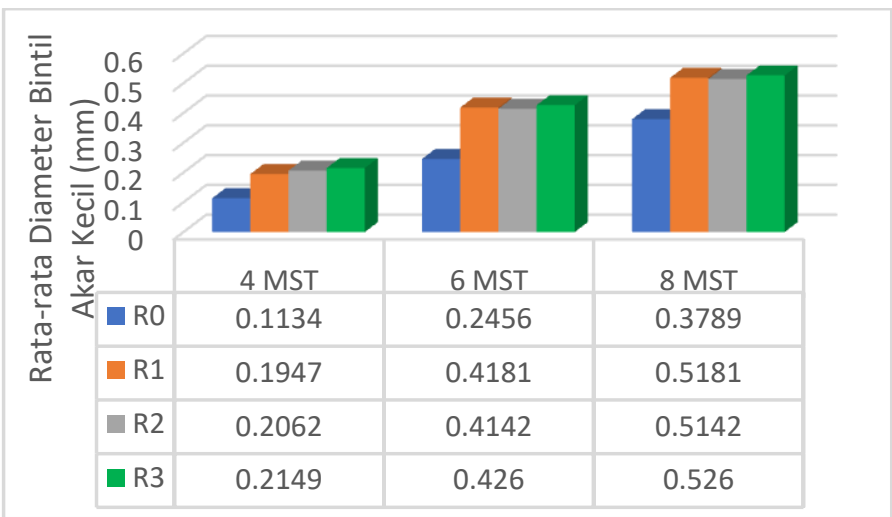

Figure 14 Diameter of small root nodules from green peas treated with: without PGPR $\left(\mathrm{R}_{0}\right)$, bamboo root PGPR $\left(\mathrm{R}_{1}\right)$, mung bean root PGPR $\left(\mathrm{R}_{2}\right)$ and shy daughter PGPR $\left(\mathrm{R}_{3}\right)$.

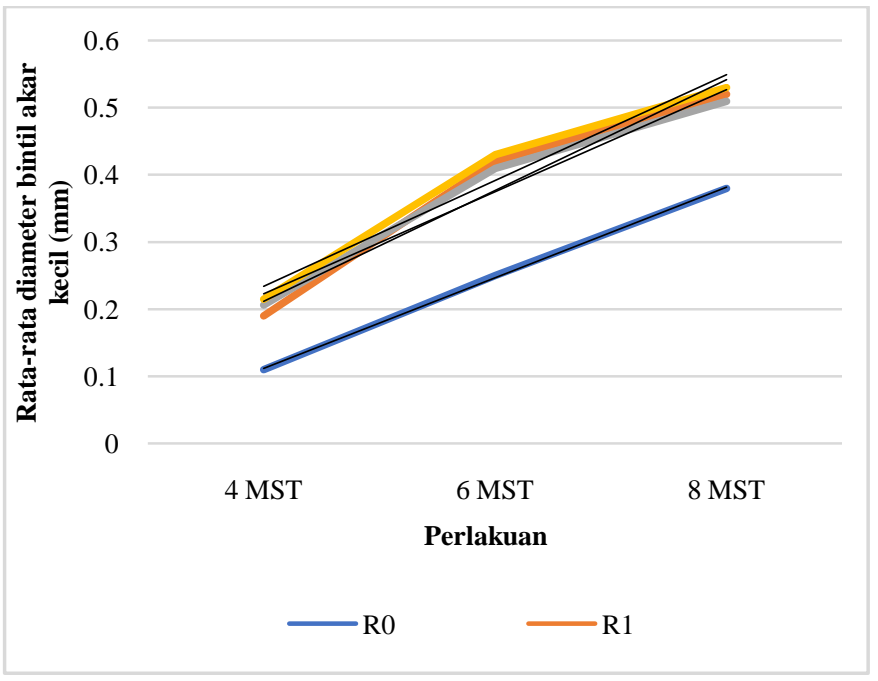

Figure 15 Regression Equation Graph 
Regression Equation

\begin{tabular}{|c|c|c|}
\hline Treatment & Regression Equation & R2 \\
\hline R0 & $\mathrm{y}=0.135 \mathrm{x}-0.0233$ & 0.9995 \\
\hline R1 & $\mathrm{y}=0.165 \mathrm{x}+0.0467$ & 0.9508 \\
\hline R2 & $\mathrm{y}=0.152 \mathrm{x}+0.0713$ & 0.9625 \\
\hline R3 & $\mathrm{y}=0.1575 \mathrm{x}+0.0767$ & 0.9575 \\
\hline
\end{tabular}

Figure 15 shows that the results were not significantly different from the PGPR type treatment on the diameter of small root nodules at the age of 4 WAP, with the highest value in the PGPR treatment of the shy daughter of the root of $0.215 \mathrm{~mm}$ and the lowest in the treatment without PGPR which was $0.11 \mathrm{~mm}$, as well as at the age of 6 WAP the difference was not significant. with the highest value in the PGPR treatment of the roots of the malu Putri, namely 0.43 $\mathrm{mm}$ and the lowest in the no PGPR, which is $0.25 \mathrm{~mm}$, at the age of $8 \mathrm{MST}$ also showed an insignificant difference with the highest value in the PGPR treatment of the roots of the malu daughter, which was $0.53 \mathrm{~mm}$ and the lowest in the treatment without PGPR, which was 0.38 . $\mathrm{mm}$.

The results showing the combination of cultivars and types of PGPR on the diameter of large root nodules are presented in Figure 7

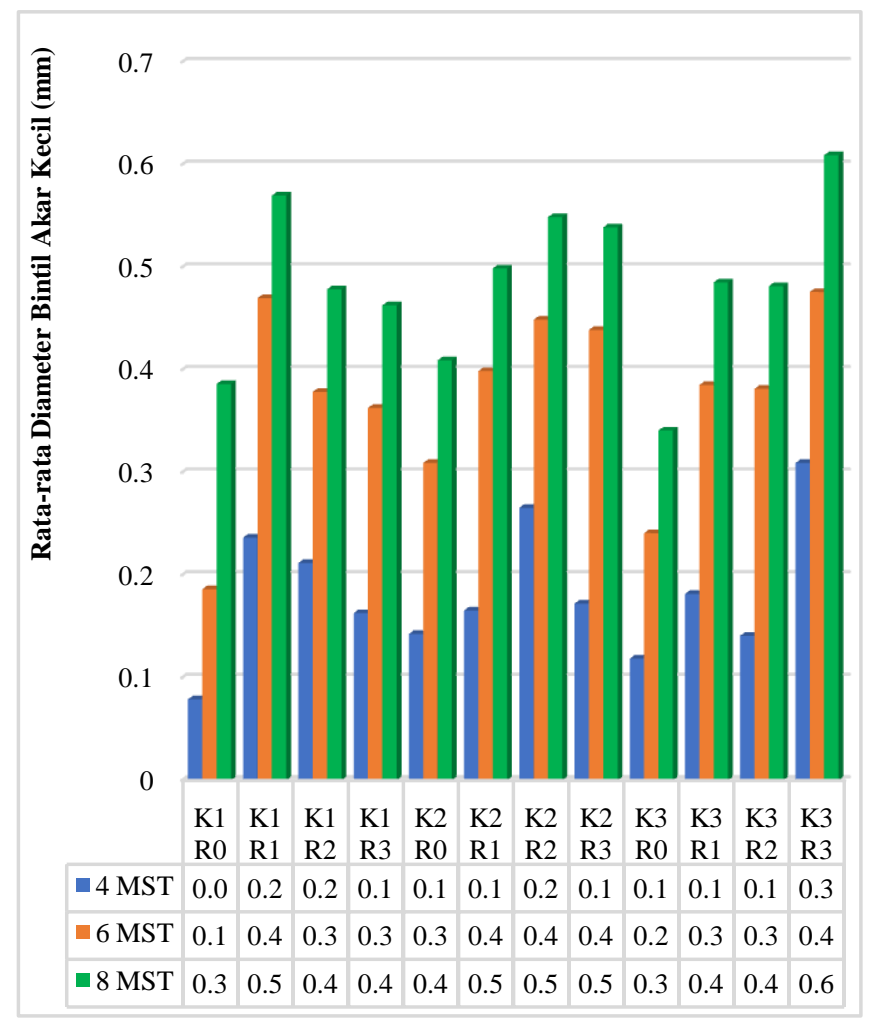

Figure 16 Small Nodule Diameter based on the combination of Cultivars and PGPR types.

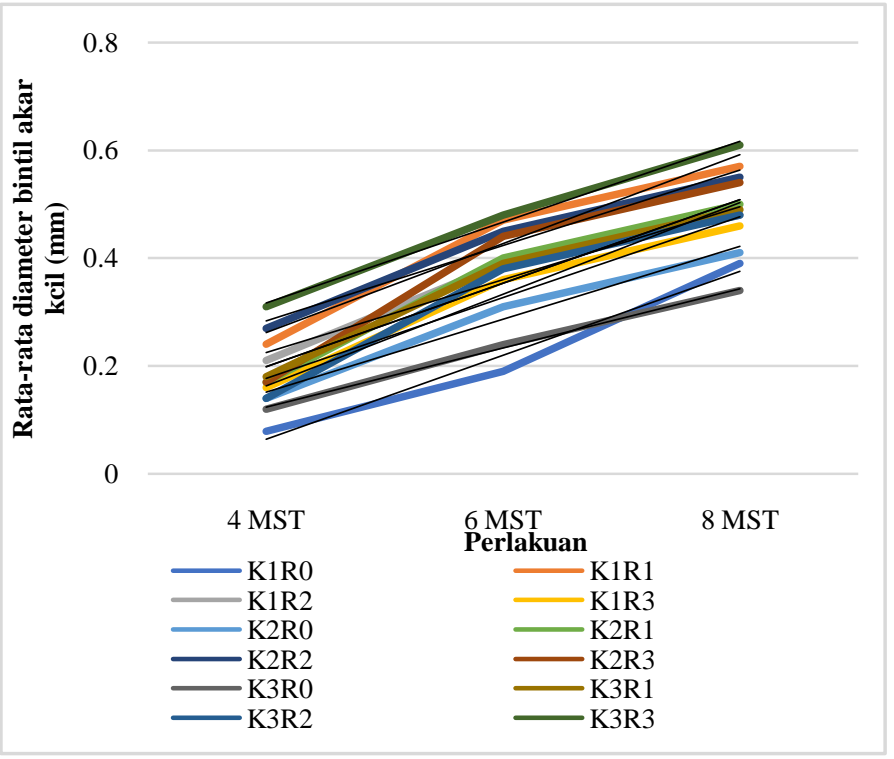

Figure 17 Regression Equation Graph

Regression Equation

\begin{tabular}{|c|c|c|}
\hline Treatment & Regression Equation & R2 \\
\hline K1R0 & $\mathrm{y}=0.1555 \mathrm{x}-0.0913$ & 0.9734 \\
\hline K1R1 & $\mathrm{y}=0.165 \mathrm{x}+0.0967$ & 0.9508 \\
\hline K1R2 & $\mathrm{y}=0.135 \mathrm{x}+0.09$ & 0.9643 \\
\hline K1R3 & $\mathrm{y}=0.15 \mathrm{x}+0.0267$ & 0.9643 \\
\hline K2R0 & $\mathrm{y}=0.135 \mathrm{x}+0.0167$ & 0.9781 \\
\hline K2R1 & $\mathrm{y}=0.165 \mathrm{x}+0.0267$ & 0.9508 \\
\hline K2R2 & $\mathrm{y}=0.14 \mathrm{x}+0.1433$ & 0.9735 \\
\hline K2R3 & $\mathrm{y}=0.185 \mathrm{x}+0.0133$ & 0.9343 \\
\hline K3R0 & $\mathrm{y}=0.11 \mathrm{x}+0.0133$ & 0.9973 \\
\hline K3R1 & $\mathrm{y}=0.17 \mathrm{x}-0.0067$ & 0.9465 \\
\hline K3R2 & $\mathrm{y}=0.17 \mathrm{x}-0.0067$ & 0.9465 \\
\hline K3R3 & $\mathrm{y}=0.15 \mathrm{x}+0.1667$ & 0.9941 \\
\hline
\end{tabular}

Figure 7 shows the results that are not significantly different from the combination of cultivars with the type of PGPR on the diameter of large root nodules at the age of 4 WAP, with the highest value in the treatment of Cultivars Vima 3 PGPR root of Putri malu (K3R3) which is $0.31 \mathrm{~mm}$ and the lowest is in the treatment of cultivar Vima 1 without PGPR ( K1R0) was $0.079 \mathrm{~mm}$, as well as at the age of 6 WAP, the difference was not significant with the highest value in the treatment of Cultivars Vima 3 PGPR root of Putri malu (K3R3) which was $0.48 \mathrm{~mm}$ and the lowest was in the cultivar Vima 1 without PGPR (K1R0) which was $0.19 \mathrm{~mm}$, at the age of $8 \mathrm{MST}$ also showed an insignificant difference with the highest value in the treatment of cultivar vima 3 PGPR root of Putri malu (K3R3) which was $0.61 \mathrm{~mm}$ and the lowest value in the treatment of cultivar Vima 3 without PGPR (K3R0) which was $0.34 \mathrm{~mm}$. 


\section{REFERENCE}

[1] Audrey, D. A. D., Stanley, Tabaraka, K. S., Lazaro, A., \& Budiharto, W. (2021). Monitoring Mung Bean's Growth using Arduino. Procedia Computer Science, 179, 352-360. https://doi.org/10.1016/j.procs.2021.01.016

[2] Brishti, F. H., Chay, S. Y., Muhammad, K., Ismail-Fitry, M. R., Zarei, M., \& Saari, N. (2021). Texturized mung bean protein as a sustainable food source: Effects of extrusion on its physical, textural and protein quality. Innovative Food Science \& Emerging Technologies, 67,

102591. https://doi.org/10.1016/j.ifset.2020.102591

[3] Bukhat, S., Imran, A., Javaid, S., Shahid, M., Majeed, A., \& Naqqash, T. (2020). Communication of plants with microbial world: Exploring the regulatory networks for PGPR mediated defense signaling. Microbiological Research, 238, 126486. https://doi.org/10.1016/j.micres.2020.126486

[4] Essalimi, B., Esserti, S., Rifai, L. A., Koussa, T., Makroum, K., Belfaiza, M., Rifai, S., Venisse, J. S., Faize, L., Alburquerque, N., Burgos, L., Jadoumi, S. E., \& Faize, M. (2022). Enhancement of plant growth, acclimatization, salt stress tolerance and verticillium wilt disease resistance using plant growth-promoting rhizobacteria (PGPR) associated with plum trees (Prunus domestica). Scientia Horticulturae, 291, 110621. https://doi.org/10.1016/j.scienta.2021.110621

[5] Favero, V. O., de Carvalho, R. H., Leite, A. B. C., de Freitas, K M., Zilli, J. É., Xavier, G. R., Rumjanek, N. G., \& Urquiaga, S. (2021). Characterization and nodulation capacity of native bacteria isolated from mung bean nodules used as a trap plant in Brazilian tropical soils. Applied Soil Ecology, 167, 104041. https://doi.org/10.1016/j.apsoil.2021.104041

[6] Gong, X., Dang, K., Lv, S., Zhao, G., Tian, L., Luo, Y., \& Feng, B. (2020). Interspecific root interactions and water-use efficiency of intercropped proso millet and mung bean. European Journal of Agronomy, 115, 126034. https://doi.org/10.1016/j.eja.2020.126034

[7] Guimarães, B. P., Nascimento, P. G. B. D., \& Ghesti, G. F. (2021). Intellectual property and plant variety protection: Prospective study on Hop (Humulus lupulus L.) cultivars. World Patent Information, $65, \quad 102041$ https://doi.org/10.1016/j.wpi.2021.102041

[8] Li, H., Qiu, Y., Yao, T., Ma, Y., Zhang, H., \& Yang, X. (2020). Effects of PGPR microbial inoculants on the growth and soil properties of Avena sativa, Medicago sativa, and Cucumis sativus seedlings. Soil and Tillage Research, 199, 104577. https://doi.org/10.1016/j.still.2020.104577

[9] Moncada, A., Miceli, A., \& Vetrano, F. (2021). Use of plant growth-promoting rhizobacteria (PGPR) and organic fertilization for soilless cultivation of basil. Scientia Horticulturae, 275, 109733. https://doi.org/10.1016/j.scienta.2020.109733

[10] Narasimha Murthy, K., Soumya, K., Udayashankar, A. C., Srinivas, C., \& Jogaiah, S. (2021). Biocontrol potential of plant growth-promoting rhizobacteria (PGPR) against Ralstonia solanacearum: Current and future prospects. In Biocontrol Agents and Secondary Metabolites (pp. 153-180). Elsevier. https://doi.org/10.1016/B978-0-12-822919-4.00007-7

[11] Razakatiana, A. T. E., Trap, J., Baohanta, R. H., Raherimandimby, M., Le Roux, C., Duponnois, R., Ramanankierana, H., \& Becquer, T. (2020). Benefits of dual inoculation with arbuscular mycorrhizal fungi and rhizobia on Phaseolus vulgaris planted in a low-fertility tropical soil. Pedobiologia, 83, 150685. https://doi.org/10.1016/j.pedobi.2020.150685

[12] Saleem, S., Iqbal, A., Ahmed, F., \& Ahmad, M. (2021). Phytobeneficial and salt stress mitigating efficacy of IAA producing salt tolerant strains in Gossypium hirsutum. Saudi Journal of Biological Sciences, 28(9), 5317-5324. https://doi.org/10.1016/j.sjbs.2021.05.056

[13] Sonbarse, P. P., Kiran, K., Sharma, P., \& Parvatam, G. (2020). Biochemical and molecular insights of PGPR application for the augmentation of carotenoids, tocopherols, and folate in the foliage of Moringa oleifera. Phytochemistry, 179, 112506. https://doi.org/10.1016/j.phytochem.2020.112506

[14] Yuan, Y., Chu, D., Fan, J., Zou, P., Qin, Y., Geng, Y., Cui, Z., Wang, X., Zhang, C., Li, X., Clark, J., Li, Y., \& Wang, X. (2021). Ecofriendly conversion of algal waste into valuable plant growthpromoting rhizobacteria (PGPR) biomass. Waste Management, 120, 576-584. https://doi.org/10.1016/j.wasman.2020.10.020

[15] Zerrouk, I. Z., Rahmoune, B., Auer, S., Rößler, S., Lin, T., Baluska, F., Dobrev, P. I., Motyka, V., \& Ludwig-Müller, J. (2020). Growth and aluminum tolerance of maize roots mediated by auxin- and cytokinin-producing Bacillus toyonensis requires polar auxin transport. Environmental and Experimental Botany, 176, 104064. https://doi.org/10.1016/j.envexpbot.2020.104064 